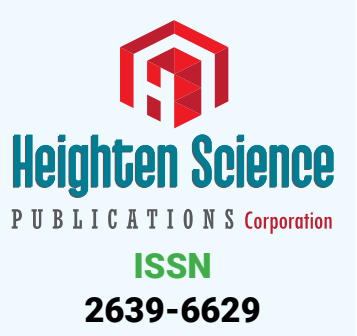

*Address for Correspondence: Alexander $E$ Berezin, Professor, MD, PhD, Senior Consultant of Therapeutic Unit, Internal Medicine Department, State Medical University of Zaporozhye, 26, Mayakovsky av., Zaporozhye, Ukraine, Tel: +380612894585; ORCID: 00000002-0446-3999; Email: aeberezin@gmail.com; dr_berezin@mail.ru

Submitted: 12 June 2019

Approved: 26 June 2019

Published: 27 June 2019

Copyright: () 2019 Berezin AE, et al. This is an open access article distributed under the Creative Commons Attribution License, which permits unrestricted use, distribution, and reproduction in any medium, provided the original work is properly cited

Keywords: Platelet-derived vesicles; Atrial fibrillation; Cardiovascular risk; Endothelial dysfunction; Prediction; Prognosis

Check for updates
Mini Review

\section{Circulating platelet-derived vesicle in atrial fibrillation}

\author{
Alexander E Berezin ${ }^{1 *}$ and Alexander A Berezin ${ }^{2}$ \\ 'Professor, MD, PhD, Senior Consultant of Therapeutic Unit, Internal Medicine Department, \\ State Medical University of Zaporozhye, 26, Mayakovsky av, Zaporozhye, Ukraine \\ ${ }^{2} \mathrm{MD}$, Internal Medicine Department, Medical Academy of Postgraduate Education, \\ Zaporozhye, Ukraine
}

\section{Abstract}

Platelet vesiculation is common factor contributing in coagulation and thromboembolism in patients with atrial fibrillation (AF). Platelet-derived vesicles are involved in the coagulation, thromboembolism, microvascular inflammation, arterial stiffness, vascular calcification, atherosclerotic plaque shaping and rupture, endothelial dysfunction, cardiac remodelling, and kidney dysfunction. Recent clinical studies have revealed elevated concentrations of plateletderived vesicles in peripheral blood of patients with current AF and history of AF. The aim of the mini review is to discuss the role of platelet-derived micro vesicles as predictive biomarker in AF. Serial measures of circulating levels of platelet-derived vesicules are discussed to be useful in stratification of AF patients at risk of thromboembolic complications, but there is limiting evidence regarding their predictive value that requires further investigations in large clinical trials.

\section{Introduction}

Extracellular vesicles (EVs) are defined as exosomes that deliver biologically active molecules (peptides, RNAs, active molecules, growth factors, hormones, enzymes) from mother cells to recipient cells through binding, fusion or endocytosis appearing to be a core element in cell-to-cell cooperation $[1,2]$. They are involved in the pathogenesis of cardiovascular (CV) diseases through several biological mechanisms that support microvascular inflammation, arterial stiffness, vascular calcification, atherosclerotic plaque shaping and rupture, endothelial dysfunction, hypercoagulation and thrombosis, cardiac remodelling, and kidney dysfunction [3,4]. Additionally, via intracellular signaling cascades EVs play a pivotal role in tissue reparation, angiogenesis, and neovascularization $[5,6]$. In fact, EVs mediate autocrine and paracrine signals that are enabled to reconstructing the homeostatic micro-environment in heart and vessels [7]. EVs are released a wide spectrum of cells, including endothelial cells, cardiomyocytes, red blood cells, mononuclears / macrophages, as well as platelets. EVs, which are produced by endothelial precursors and mature endothelial cells, as well as mononuclears, are under investigations for long time respectively and there is evidence regarding predictive capability of altered circulating number of EVs in established CV disease including arrhythmias [8,9]. On contrary, the exact role of platelet-derived micro vesicles in pathogenesis of atrial fibrillation remains to be not fully discovered, although there was evidence that elevated levels of platelet-derived vesicles was able to predict systemic thromboembolic complications [5,8]. The aim of the mini review is to discuss the role of platelet-derived micro vesicles as predictive biomarker in atrial fibrillation (AF). 


\section{Extracellular vesicles: definition}

Extracellular vesicles (EVs) are defined as cell membranous originated structures with a size $<1000 \mathrm{~nm}$ that are secreted by various cells (platelets, red and white blood cells, endothelial cells, precursors / stem cells, cardiomyocytes, and even tumor cells) into human fluids and contained wide range of proteins, hormones, signalling molecules, lipids, mRNA, miRNA, and others $[10,11]$. There are at least two distinct subpopulations of EVs (exosomes and micro vesicles [MVs]), which distinguish each other in size, compounds, immune phenotypes and wide range of formation modes (Figure). Exosomes are sufficiently smaller to MVs (size averages are $30-120 \mathrm{~nm}$ and 40-1000 nm respectively) and are shaped by the endocytosis of multivesicular bodies and are shed from cells by exocytosis. On contrary, MVs are defined as membranebound vesicles, which are released from the plasma membrane. Additionally, surfacespecific antigens, which are presented for both populations of EVs, are different, but they overlap between exosomes and MVs that does not allow differencing both populations of the particles. Physiologically, EVs are a cargo for molecule transfer, auto / paracrine signalling, cell-to-cell cooperation, playing a pivotal role in immune response, vascular integrity, cellular senescence, tissue reparation and development, angiogenesis and neovascularization [12,13]. In fact, EVs are able to mediate the exchange of appropriate information between various cells. EVs were found witness and biomarkers of several diseases, such as CV, autoimmune, infective, metabolic, renal, rheumatic, neurological, ocular diseases and malignancy [14-17].

\section{Platelet-derived vesicles}

The population of the platelet-derived vesicles is the largest in other types of EVs in the circulation. Indeed, the majority of the blood-borne EVs are thought to originate from the megakaryocytes, i.e. either from circulating platelets or directly from the platelet precursor cells, which reside in the bone marrow. Although coagulation, thrombosis, vascular senescence and permeability are most common and well established biological function of platelet-derived vesicles, the role of them in CV diseases has not exhausted a crucial impact on hemostasis. Elevated levels of platelet-derived vesicles were determined in patients with acute coronary syndrome, myocardial infarction, as well as heparin-induced thrombocytopenia, thrombotic complications, hemolytic uremic syndrome, while developing of abdominal obesity, diabetes mellitus, antiphospholipid

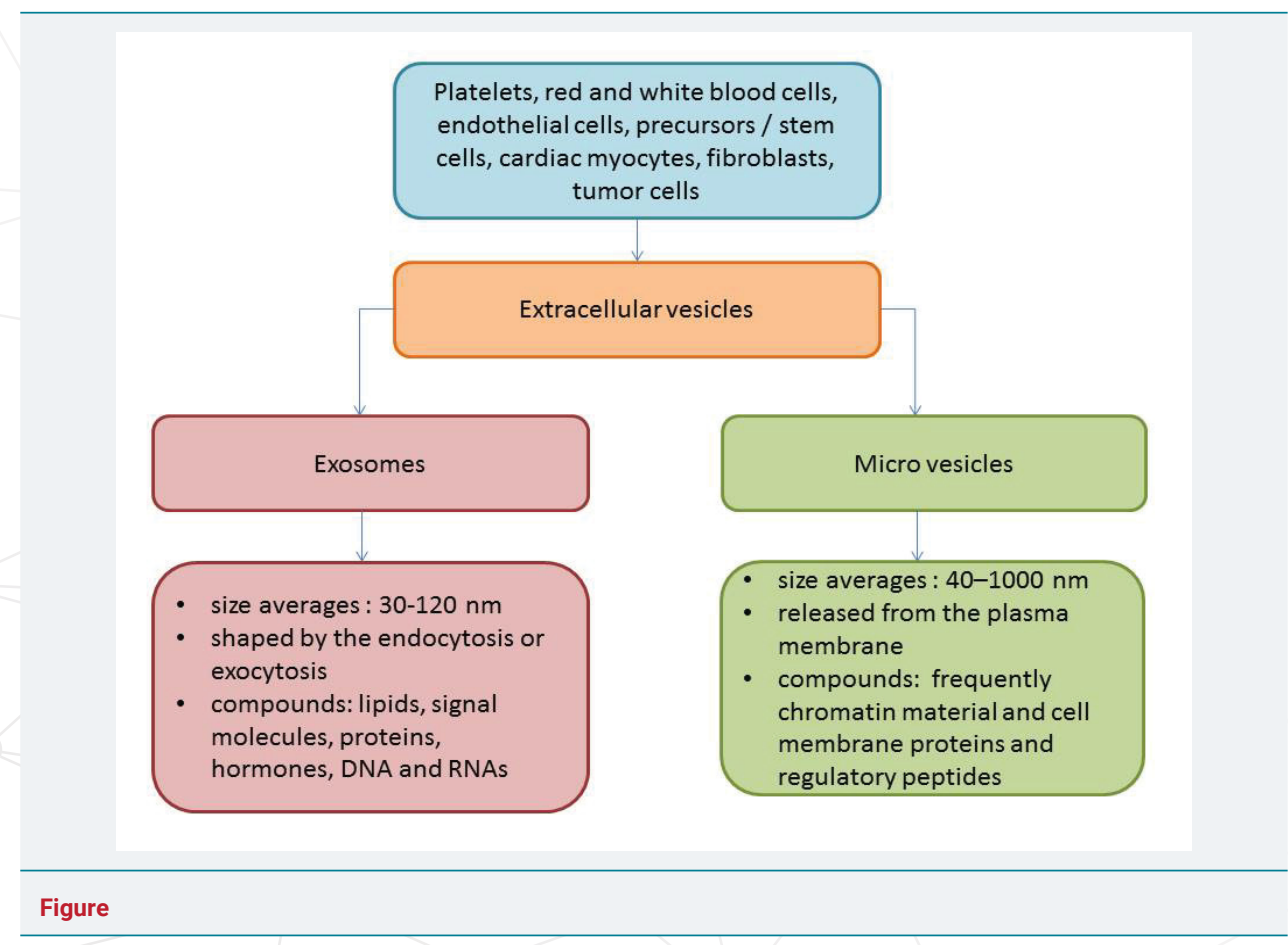


syndrome, and sepsis was not associated with increased circulating level of plateletderived vesicles [18]. Probably, this evidence might relate to the mechanisms regarding release of MPs from platelets. It has suggested that in various cases circulating platelets are likely to adhere to leukocytes or endothelial cells at the activation site and that the circulating platelet-derived MPs are likely to be a residue of activated platelets [19].

It has been found that upon activation, blood platelets are able to release two types of EVs, i.e. micro particles and exosomes. Platelet-derived micro particles are characterized by average of size of 70-100 nm and the phosphatidylserine (PS) presentation at their surface, which mediates their capabilities in coagulation and thrombosis [20]. On contrary, platelet-derived exosomes are characterized by their small size $(<80 \mathrm{~nm})$ and the presence of CD63 antigen, which is known as the tetraspanin that belongs to the transmembrane 4 superfamily $[19,20]$. CD63 plays a pivotal role in the role in the activation of cellular signalling cascades that trigger AkT, FAK-related non-kinase polypeptide / protein tyrosine kinase-2 (PTK-2) and mitogenactivated protein (MAP) kinases, attenuates an adhesion of circulating monocytes / macrophages onto endothelial cells through the regulation of P-selectin (CD62) trafficking, as well as promotes vascular endothelial growth factor receptor (VEGFR) signalling and internationalization [21]. All these factors are embedded into cell-tocell cooperation and cell interactions with the extracellular matrix. Moreover, EVs expressing Ms4a2/FceRI on the surface are able to be triggers for degranulation of circulating cell in response to other stimuli [22]. Additionally, some EVs may express CD41 (Integrin alpha-IIb) on their surface, which in a complex with CD61 may be a receptor for thrombospondin, fibronectin, vitronectin, fibrinogen, and von Willebrand factor playing a crucial role in blood coagulation [22, 23]. The populations of the platelet-derived EVs may distinguish each other in not just their size and immune phenotype, but yet they could have different in density (utilized as sucrose density gradient in ultracentrifugation), proteomic and lipidomic profiles [24] Labeling of platelet-derived EVs is reported in the table 1.

Although there is difficulties in identification of distinction between both two types of EVs (micro particles and exosomes) in cargo potency, immune heterogeneity and size averaging of $\mathrm{EV}$ populations allows identifying them using several methods for their isolation and quantification, including conventional and cryo-enhanced electron microscopy, immuno-gold labelling, laser-scanning confocal microscopy, nanoparticle tracking analysis and flow cytometry [25,26] However, lack of generally accepted methods as a standard for determination, isolation and quantification of plateletderived EVs, sufficiently limits our efforts in understanding their biological role in the pathogenesis of several states and diseases [27,28].

\section{Platelet-derived vesicles in CV disease}

There is large body of evidence regarding pivotal role of platelet-derived vesicles in the pathogenesis of CV diseases [29-31]. In a result of several triggers, such as ischemia, hypoxia, anemia, inflammation, shear stress, blood turbulence, platelets are activated, aggregated, then they changed their contain enriching phospholipids and GPs, prepare for vesiculation via shaping spaced architectonic and exocytosis and release vesicles into circulation. Regulation platelet vesiculation is mediated via platelet $\mathrm{Ca}(2+)$ ATPases by cyclic AMP through the phosphorylation of the Rap1 protein.

Platelet-derived vesicles exhibit haemostatic properties, mediated aggregation of blood cells including whole platelets, promote coagulation, stabilize the vasculature and maintain endothelial cell barrier integrity [32]. Therefore, platelet-derived vesicles may demonstrate pro-atherogenic, pro-inflammatory, and immunomodulatory, even anticoagulant activity depending on triggers that induce their releasing and the expression of their surface certain molecules [33-35]. For instance, phospholipidenriched platelet-derived vesicles that express Annexin $V$ possess as pro-atherogenic 
Table 1: Labelling of platelet-derived EVs with surface CD markers.

\begin{tabular}{|c|c|c|c|c|c|}
\hline CD marker & Alternative name & Prominent feature & Cell labelling & Expression & Significance \\
\hline CD9 & $\begin{array}{l}\text { Tetraspanin (Tspan } \\
\text { 29) }\end{array}$ & $\begin{array}{c}\text { Key regulator of intracellular signalling, } \\
\text { proliferation, activation, survival, } \\
\text { migration, invasion, cell adhesion, and } \\
\text { diapedesis }\end{array}$ & $\begin{array}{l}\text { Platelets, B cells, CD4+ T cells, } \\
\text { CD8+ T cells, natural killer cells, } \\
\text { granulocytes, monocytes and } \\
\text { macrophages, and immature and } \\
\text { mature dendritic cells }\end{array}$ & Low & $\begin{array}{c}\text { None-specific lympho / hematopoietic } \\
\text { marker }\end{array}$ \\
\hline CD23 & $\begin{array}{l}\text { Fc epsilon RII } \\
\quad \text { (FcعRII) }\end{array}$ & $\begin{array}{l}\text { Interaction with many ligands (IgE, } \\
\text { CD21, MHC class Il,integrins), exhibiting } \\
\text { pleiotropic cytokine-like activities, } \\
\text { sustaining the growth of activated B-cells, } \\
\text { differentiation of myeloid precursors, } \\
\text { thymocytes and bone marrow CD4+ T } \\
\text { cells, degranulation of platelets }\end{array}$ & $\begin{array}{l}\text { Platelets, } T \text { and B lymphocytes, } \\
\text { polymorphonuclear leucocytes, } \\
\text { monocytes, follicular dendritic } \\
\text { cells, intestinal epithelial cells, } \\
\text { bone marrow stromal cells }\end{array}$ & Low & $\begin{array}{c}\text { None-specific lymphohematopoietic marker, } \\
\text { diagnostic marker for neoplastic and } \\
\text { autoimmune inflammatory disease }\end{array}$ \\
\hline CD31 & $\begin{array}{l}\text { PECAM-1, GP Ila, } \\
\text { hec7 antigen, } \\
\text { EndoCAM }\end{array}$ & $\begin{array}{l}\text { Key inhibitory receptor in circulating } \\
\text { platelets and leukocytes, major } \\
\text { endothelial mechanosensor, modulator } \\
\text { of vascular permeability, and leukocyte } \\
\text { trafficking, and cell-to-cell cooperation, } \\
\text { core player in in thrombosis, inflammation } \\
\text { and the immune response }\end{array}$ & $\begin{array}{l}\text { Platelets, leucocytes, monocytes } \\
\text { / mononuclears, endothelial cells, } \\
\text { EPCs }\end{array}$ & High & $\begin{array}{c}\text { A maker of endothelial integrity, vascular } \\
\text { permeability, platelet degranulation, } \\
\text { endothelialopathies in tumor angiogenesis } \\
\text { and the growth and development of } \\
\text { hemangiomas }\end{array}$ \\
\hline CD36 & GP-IV, Scarb3 & $\begin{array}{l}\text { Recognition of thrombospondine, fatty } \\
\text { acids, collagen, adhesion of platelets }\end{array}$ & $\begin{array}{c}\text { Monocytes, macrophages, } \\
\text { platelets, adipose cells, } \\
\text { endothelial cells, PECs, epithelial } \\
\text { cells }\end{array}$ & High & Platelet collagen receptor \\
\hline CD41 & $\begin{array}{l}\text { allb integrin, platelet } \\
\text { GPIIb }\end{array}$ & $\begin{array}{l}\text { Key regulator of growth and } \\
\text { differentiation }\end{array}$ & $\begin{array}{l}\text { Hematopoetic progenitors } \\
\text { in embrio, specific to the } \\
\text { megakaryocytic / platelet lineage }\end{array}$ & Moderate & $\begin{array}{c}\text { Markers of all progenitors (megakaryocytic, } \\
\text { granulomacrophagic, erythroid and } \\
\text { pluripotent cells) }\end{array}$ \\
\hline $\begin{array}{l}\text { CD42 (a, } \\
\quad b, c)\end{array}$ & $\begin{array}{l}\text { Integrin subunit allb, } \\
\text { GPIlb }\end{array}$ & $\begin{array}{l}\text { Regulator of platelet activation and } \\
\text { adhesion }\end{array}$ & Platelets & High & Marker of platelet aggregation \\
\hline CD49f & $\begin{array}{c}\text { GPIc, integrin } \\
\text { a6-chain, ITGA6, } \\
\text { ITGA6B, VLA } 6 \text { alpha } \\
\text { Subunit }\end{array}$ & $\begin{array}{l}\text { Regulator of embryogenesis, cell } \\
\text { adhesion and cell migration through T-cell } \\
\text { receptor/CD3 complex }\end{array}$ & $\begin{array}{l}\text { T cells, endothelial cells, epithelial } \\
\text { cell, macrophages, monocytes; } \\
\text { platelets and stem cell }\end{array}$ & High & $\begin{array}{l}\text { Marker of blood cell adhesion and T-cell } \\
\text { proliferation }\end{array}$ \\
\hline CD51 & $\begin{array}{l}\text { Integrin subunit } \\
\text { alpha } \mathrm{V} \text {, vitronectin } \\
\text { receptor }\end{array}$ & $\begin{array}{c}\text { Trigger of cell adhesion and signal } \\
\text { transduction, regulator of angiogenesis } \\
\text { and cancer progression }\end{array}$ & T cells, endothelial cells, platelets & High & $\begin{array}{c}\text { Marker of cell adhesion to sequences of von } \\
\text { Willebrand factor, vitronectin, fibrinogen and } \\
\text { thrombospondin }\end{array}$ \\
\hline CD61 & $\begin{array}{l}\text { GP3A, integrin } \\
\text { subunit beta } 3\end{array}$ & $\begin{array}{l}\text { Regulator of cell adhesion and cell- } \\
\text { surface mediated signalling }\end{array}$ & $\begin{array}{l}\text { Endothelial cells, Macrophage, } \\
\text { platelets }\end{array}$ & High & $\begin{array}{l}\text { Marker of human megakaryocytic cell } \\
\text { lineages }\end{array}$ \\
\hline CD84 & $\begin{array}{l}\text { Cell surface antigen } \\
\text { MAX.3, Ly-9B, } \\
\text { SLAMF-5 }\end{array}$ & $\begin{array}{l}\text { Regulator of signalling and adhesion in } \\
\text { lymphocytic cells and other cells }\end{array}$ & $\begin{array}{c}\text { Thymus and spleen cells, cells of } \\
\text { megakaryocytic lineages }\end{array}$ & Moderate & $\begin{array}{l}\text { Marker of adhesion interactions between } T \\
\text { lymphocytes and accessory cells, platelets }\end{array}$ \\
\hline CD92 & $\begin{array}{l}\text { Choline Transporter } \\
\text { like Protein } 1\end{array}$ & $\begin{array}{l}\text { Regulator of cell growth and } \\
\text { differentiation }\end{array}$ & $\begin{array}{l}\text { Subset of bone marrow stromal } \\
\text { cells, cells of osteogenic, } \\
\text { megakaryocytic and adipogenic } \\
\text { lineages }\end{array}$ & High & $\begin{array}{c}\text { Marker of human bone marrow stromal } \\
\text { cells, and cells of megakaryocytic and } \\
\text { adipogenic lineages }\end{array}$ \\
\hline CD110 & $\begin{array}{c}\text { MPL proto-oncogene, } \\
\text { TPO-R, }\end{array}$ & Regulator of heamopoesis & $\begin{array}{c}\text { Subset of stem cells and cells of } \\
\text { megakaryocytic lineage as well as } \\
\text { platelets }\end{array}$ & High & Marker of megakaryocytic lineage \\
\hline CD147 & BSG, EMMPRIN & $\begin{array}{l}\text { Trigger of cell proliferation associated } \\
\text { with the TGF- } \beta / \text { Smad } 4 \text { signalling } \\
\text { pathway, cell adhesion and T-cell } \\
\text { activation }\end{array}$ & $\begin{array}{l}\text { Endothelial cell, epithelial cells, } \\
\text { lymphocytes, mononuclears, } \\
\text { platelets }\end{array}$ & Low & $\begin{array}{c}\text { Marker of cell growth, adhesion, and } \\
\text { proliferation, malignancy, angiogenesis, } \\
\text { vascular permeability }\end{array}$ \\
\hline CD151 & $\begin{array}{l}\text { GP27, membrane } \\
\text { glycoprotein SFA-1, } \\
\text { platelet-endothelia-I } \\
\text { tetraspan antigen-3 }\end{array}$ & $\begin{array}{l}\text { Regulator of the VCAM- } 1 \text { activity during } \\
\text { lymphocyte and platelet recruitment }\end{array}$ & Endothelial cells, platelets, T-cells & High & $\begin{array}{l}\text { Marker of fibrosis, vascular inflammation } \\
\text { and remodelling, cancinogenesis, vascular } \\
\text { permeability, endothelial dysfunction }\end{array}$ \\
\hline CD226 & $\begin{array}{l}\text { DNAM1, PTA1, } \\
\text { TLISA1, DNAX }\end{array}$ & $\begin{array}{c}\text { An adhesion molecule involved in NK and } \\
\text { T cell-mediated cytotoxicity }\end{array}$ & $\begin{array}{l}\text { T cells, NK cells, platelets, } \\
\text { mononuclears }\end{array}$ & Low & $\begin{array}{l}\text { Triggering cytotoxicity and cytokine } \\
\text { secretion by T and NK cells }\end{array}$ \\
\hline GARP & & $\begin{array}{l}\text { A key regulator of network between } \mathrm{T}_{\text {regs }} \\
\text { and its targets }\end{array}$ & $\begin{array}{l}\text { Activated } T_{\text {regs }} \text { mature peripheral } \\
\text { naive } C D 4+T \text { cells, platelets }\end{array}$ & Low & $\begin{array}{c}\text { Marker of activated } T_{\text {regs }} \text { and degradated } \\
\text { platelets }\end{array}$ \\
\hline LAP & & $\begin{array}{c}\text { Phagosome maturation, stabilization of } \\
\text { the cargo to prolong antigen presentation } \\
\text { on MHC, recruiting LC3 molecules } \\
\text { to phagosome membranes class II } \\
\text { molecules }\end{array}$ & $\begin{array}{l}\text { Macrophages, dendritic cells and } \\
\text { platelets }\end{array}$ & Low & $\begin{array}{l}\text { A marker of catabolic process involved } \\
\text { during exogenous antigen processing, } \\
\text { recognition of apoptotic, necrotic, or entotic } \\
\text { cells, degradation of platelets }\end{array}$ \\
\hline
\end{tabular}

Abbreviation: MHC, major histocompatibility complex; GP, glycoprotein; PECAM-1, platelet/endothelial cell adhesion molecule 1; EPCs, endothelial progenitor cells; NK, nature killer; TPO-R, thrombopoietin receptor; BSG, basigin; EMMPRIN, extracellular matrix metalloproteinase inducer; TGF- $\beta$, transforming growth factor-beta; SLAMF-5, Signalling lymphocytic activation molecule 5; LAP, LC3-associated phagocytosis; GARP, glycoprotein A repetitions predominant. 
and pro-coagulant particles [36]. On contrary Annexin V-negative vesicles were found rather anticoagulant than pro-coagulant particles. Therefore, platelets contain S100A8/A9 in membrane-enclosed vesicles and transfer it to target cells including endothelial cells and their precursors [37]. Probably S100A8/A9-rich plateletderived vesicles can play a pivotal role in developing endothelial dysfunction upon manifestation of CV disease. Additionally, platelet-derived vesicles deliver oxidized lipids, P-selectin / P-selectin glycoprotein ligand 1 (PSGL-1), CD40 ligand (CD154) and induce B-cell synthesis and secretion of antigen-specific immunoglobulin G and potentiate the adaptive immune response through CD4+ cells [38-40] Although restored endothelial cell junctions and vascular integrity after thrombin releasing, the balance between promoting coagulation and mitigating endothelial dysfunction and vascular permeability has being turn to the side of potentiation of platelet activation status and pro-coagulant activity [41]. This effect appears to be harmful for majority patients with established CV diseases including asymptomatic atherosclerosis, acute coronary syndrome / myocardial infarction, hypertension, hypertensive crisis, heart failure, peripheral artery disease.

\section{Platelet-derived vesicles in atrial fibrillation}

Atrial fibrillation (AF) is the most common cardiac arrhythmia, which is strongly associated with heart failure, sudden death, the pro-coagulant state and thromboembolic events including stroke, pulmonary thromboembolism [42]. Recent studies have shown that AF patients had significantly higher levels of total circulating vesicles originated from various cells including platelets to other individuals without $\mathrm{AF}$ and healthy volunteers [43-45]. It has found that numerous mechanisms that are associated with AF developing, such as hypoxia / ischemia, low or oscillatory shear stress, stretching, high ventricular heart rate, systemic low-grading inflammation and oxidative stress, are potent inducers of apoptotic cell death, which leads to the shedding of pro-coagulant vesicles within the vasculature [46]. Phosphatidylserine positive platelet-derived vesicles were found in elevated concentrations in peripheral blood collected from patients with permanent form of AF, while preserving sinus rhythm in post-AF / pre-AF periods in persistent form of AF was associated with increased levels of platelet-derived vesicles with pro-coagulant capacity, but sufficiently lower in comparison with permanent AF patients [45-47]. However, the clinical studies have revealed that decreased apoptotic and lipid-rich platelet-derived vesicles after the restoration of sinus rhythm might enable restoration of haemostasis and reduce a risk of stroke and several thromboembolisms [46,47] Conversely, there is evidence regarding that the platelet activation and its ability to release pro-coagulant P-selectin / phosphatidylcholine-rich vesicles in AF patients is result of underlying CV diseases rather than the $\mathrm{AF}$ per se [46-48]. Interestingly, acetylsalicylic acid-clopidogrel combination therapy failed to reduce circulating biomarkers of thrombogenesis and platelet activation including a number of platelet-derived vesicles in patients with any form of AF. On contrary, oral anticoagulants, such as vitamin $\mathrm{K}$ antagonists and novel oral anticoagulants, appear to be superior to combination acetylsalicylic acidclopidogrel therapy in suppression platelet vesiculation and thereby in prevention of AF-related thrombotic complication [49,50]. Additional study is required to further elucidate the core role of circulating platelet-derived vesicles in the pathophysiology of AF and its complications. Finally, whether measure of circulating levels of plateletderived vesicles is useful to determine a high risk among AF patients is not fully understood and required to be elucidated in large clinical trials.

\section{Conclusion}

Platelet vesiculation is common factor contributing in coagulation and thromboembolism in patients with AF. Serial measures of circulating levels of plateletderived vesicules can be useful to stratify AF patients at risk of thromboembolic 
complications. Further investigations are required to clearly understand a role of circulating pool of platelet-derived vesicles in prediction of poor prognosis in $\mathrm{AF}$ individuals.

\section{References}

1. Shanmuganathan M, Vughs J, Noseda M, Emanueli C. Exosomes: Basic Biology and Technological Advancements Suggesting Their Potential as Ischemic Heart Disease Therapeutics. Front Physiol. 2018; 9: 1159. Ref.: https://tinyurl.com/yxa5gxag

2. Berezin A, Zulli A, Kerrigan S, Petrovic D, Kruzliak P. Predictive role of circulating endothelialderived microparticles in cardiovascular diseases. Clin Biochem. 2015; 4: 562-568. Ref.: https://tinyurl.com/yyf9f8ds

3. Nawaz M, Shah N, Zanetti BR, Maugeri M, Silvestre RN, et al. Extracellular Vesicles and Matrix Remodeling Enzymes: The Emerging Roles in Extracellular Matrix Remodeling, Progression of Diseases and Tissue Repair. Cells. 2018; 7. Ref.: https://tinyurl.com/y4ouroko

4. La Marca V, Fierabracci A. Insights into the Diagnostic Potential of Extracellular Vesicles and Their miRNA Signature from Liquid Biopsy as Early Biomarkers of Diabetic Micro/Macrovascular Complications. Int J Mol Sci. 2017; 18. Ref.: https://tinyurl.com/y5jexz6r

5. Berezin AE, Kremzer AA, Berezina TA, Martovitskaya YV. Pattern of circulating microparticles in chronic heart failure patients with metabolic syndrome: Relevance to neurohumoral and inflammatory activation. BBA Clin. 2015; 4: 69-75. Ref.: https://tinyurl.com/y3jb5jdj

6. Caporali A, Martello A, Miscianinov V, Maselli D, Vono R, et al. Contribution of pericyte paracrine regulation of the endothelium to angiogenesis. Pharmacol Ther. 2017; 171: 56-64. Ref.: https://tinyurl.com/y5jn9uel

7. De Toro J, Herschlik L, Waldner C, Mongini C. Emerging roles of exosomes in normal and pathological conditions: new insights for diagnosis and therapeutic applications. Front Immunol. 2015; 6: 203. Ref.: https://tinyurl.com/y3cxpv8a

8. Berezin AE. Microparticles in Chronic Heart Failure. Adv Clin Chem. 2017; 81: 1-41. Ref.: https://tinyurl.com/y3v76f6

9. Berezin $A E$, Kremzer AA, Cammarota G, Zulli A, Petrovic D, et al. Circulating endothelial-derived apoptotic microparticles and insulin resistance in non-diabetic patients with chronic heart failure. Clin Chem Lab Med. 2016; 54: 1259-1267. Ref.: https://tinyurl.com/yxtq8m22

10. Chen BY, Sung CW, Chen C, Cheng CM, Lin DP, et al. Advances in exosomes technology. Clin Chim Acta. 2019; 493:14-19. Ref.: https://tinyurl.com/y37eudtp

11. Juan T, Fürthauer M. Biogenesis and function of ESCRT-dependent extracellular vesicles. Semin Cell Dev Biol. 2018; 74: 66-77. Ref.: https://tinyurl.com/yxwl6syy

12. Hervera A, Santos CX, De Virgiliis F, Shah AM, Di Giovanni S. Paracrine Mechanisms of Redox Signalling for Postmitotic Cell and Tissue Regeneration. Trends Cell Biol. 2019; 29: 514-530. Ref.: https://tinyurl.com/yyxmmqb7

13. Mobarak H, Heidarpour M, Lolicato F, Nouri M, Rahbarghazi R, et al. Physiological impact of extracellular vesicles on female reproductive system; highlights to possible restorative effects on female age-related fertility. Biofactors. 2019; 45: 293-303. Ref.: https://tinyurl.com/y35o3nt2

14. Navarro A, Molins L, Marrades RM, Moises J, Viñolas N, et al. Exosome Analysis in Tumor-Draining Pulmonary Vein Identifies NSCLC Patients with Higher Risk of Relapse after Curative Surgery. Cancers. 2019; 11. Ref.: https://tinyurl.com/y5lxo9ux

15. Aslan C, Maralbashi S, Salari F, Kahroba H, Sigaroodi F, et al. Tumor-derived exosomes: Implication in angiogenesis and antiangiogenesis cancer therapy. J Cell Physiol. 2019. Ref.: https://tinyurl.com/y4qgmaet

16. Yang $L$, Zhu J, Zhang $C$, Wang J, Yue $F$, et al. Stem cell-derived extracellular vesicles for myocardial infarction: a meta-analysis of controlled animal studies. Aging (Albany NY). 2019; 11: 1129-1150. Ref.: https://tinyurl.com/y48bbwz5

17. Bei $Y$, Das $S$, Rodosthenous RS, Holvoet $P$, Vanhaverbeke $M$, et al. Extracellular Vesicles in Cardiovascular Theranostics. Theranostics. 2017; 7: 4168-4182. Ref.: https://tinyurl.com/yxadvxs7

18. Kenari AN, Kastaniegaard K, Greening DW, Shambrook M, Stensballe A, et al. Exosome-mimetic nanovesicles contain distinct proteome and post-translational modified protein cargo, in comparison to exosomes. Proteomics. 2019; e1800161. 
19. Vagner T, Chin A, Mariscal J, Bannykh S, Engman D, et al. Protein composition reflects extracellular vesicle heterogeneity. Proteomics. 2019; 19: e1800167. Ref.: https://tinyurl.com/y5mdty6d

20. Aatonen $M$, Valkonen $S$, Böing $A$, Yuana $Y$, Nieuwland $R$, et al. Isolation of Platelet-Derived Extracellular Vesicles. Methods Mol Biol. 2017; 1545: 177-188. Ref.: https://tinyurl.com/y4szfu9h

21. Hedley BD, Llewellyn-Smith N, Lang S, Hsia CC, MacNamara N, et al. Combined accurate platelet enumeration and reticulated platelet determination by flow cytometry. Cytometry B Clin Cytom. 2015; 88: 330-337. Ref.: https://tinyurl.com/yxmpworn

22. Bennett JS. The molecular biology of platelet membrane proteins. Semin Hematol. 1990; 27: 186204. Ref.: https://tinyurl.com/y2235ydv

23. Clemetson KJ, Clemetson JM. Platelet GPIb complex as a target for anti-thrombotic drug development. Thromb Haemost. 2008; 99: 473-479. Ref.: https://tinyurl.com/y42x8bgg

24. Chevillet JR, Kang Q, Ruf IK, Briggs HA, Vojtech LN, Hughes SM, et al. Quantitative and stoichiometric analysis of the microRNA content of exosomes. Proc Natl Acad Sci. 2014; 111: 14888-14893. Ref.: https://tinyurl.com/y5nd5yax

25. Van der Pol E, Boing AN, Harrison P, Sturk A, Nieuwland R. Classification, Functions, and Clinical Relevance of Extracellular Vesicles. Pharmacological Reviews. 2012; 64: 676-705. Ref.: https://tinyurl.com/yyfpe9eb

26. Liu C, Zhao J, Tian F, Chang J, Zhang W, Sun J. $\lambda$-DNA and Aptamer Mediated Sorting and Analysis of Extracellular Vesicles. J Am Chem Soc. 2019.

27. Nolan JP, Jones JC. Detection of platelet vesicles by flow cytometry. Platelets. 2017; 28: 256-262. Ref.: https://tinyurl.com/y4y22qwm

28. Lacroix R, Robert $\mathrm{S}$, Poncelet $\mathrm{P}$, Kasthuri $\mathrm{R}$, Key $\mathrm{N}$, et al. Standardization of platelet-derived microparticle enumeration by flow cytometry with calibrated beads: results of the International Society on Thrombosis and Haemostasis SSC Collaborative workshop. J Thromb Haemost. 2010; 8: 2571-2574. Ref.: https://tinyurl.com/y6au77ef

29. Tao SC, Guo SC, Zhang CQ. Platelet-derived Extracellular Vesicles: An Emerging Therapeutic Approach. Int J Biol Sci. 2017; 13: 828-834. Ref.: https://tinyurl.com/y25zsu24

30. Zaldivia MTK, Hering D, Marusic P, Sata Y, Lee R, et al. Successful Renal Denervation Decreases the Platelet Activation Status in Hypertensive Patients. Cardiovasc Res. 2019. Ref.: https://tinyurl.com/y5stksbw

31. Zaldivia MT, Rivera J, Hering D, Marusic P, Sata Y, et al. Renal Denervation Reduces Monocyte Activation and Monocyte-Platelet Aggregate Formation: An Anti-Inflammatory Effect Relevant for Cardiovascular Risk. Hypertension. 2017; 69: 323-331. Ref.: https://tinyurl.com/yyrrpyog

32. Barnes JN, Harvey RE, Miller KB, Jayachandran M, Malterer KR. et al. Cerebrovascular Reactivity and Vascular Activation in Postmenopausal Women with Histories of Preeclampsia. Hypertension. 2018; 71: 110-117. Ref.: https://tinyurl.com/y2jjomjg

33. Van Wijk MJ, Van Bavel E, Sturk A, Nieuwland R. Microparticles in cardiovascular diseases. Cardiovasc Res. 2003; 59: 277-287. Ref.: https://tinyurl.com/yycsgewz

34. Yano Y, Kambayashi J, Shiba E, Sakon M, Oiki E. et al. The role of protein phosphorylation and cytoskeletal reorganization in microparticle formation from the platelet plasma membrane. Biochem J. 1994; 299: 303-308. Ref.: https://tinyurl.com/y4fc4acw

35. Gemmel $\mathrm{CH}$, Sefton MV, Yeo E. Platelet-derived microparticle formation involves glycoprotein IIbIIla. Inhibition by RGDS and a Glanzmann's thrombasthenia defect. J Biol Chem. 1993; 268: 1458614589. Ref.: https://www.ncbi.nlm.nih.gov/pubmed/8325838

36. Cauwenberghs S, Feijge MA, Harper AG, Sage SO, Curvers J, Heemskerk JW. Shedding of procoagulant microparticles from unstimulated platelets by integrin-mediated destabilization of actin cytoskeleton. FEBS Lett. 2006; 580: 5313-5320. Ref.: https://tinyurl.com/y3za2dbw

37. Nomura S, Komiyama Y, Miyake T, Miyazaki Y, Kido H. et al. Amyloid-protein precursor-rich platelet microparticles in thrombotic disease. Thromb Haemost. 1994; 72: 519-522. Ref.: https://tinyurl.com/y3ns39f8

38. Furie B, Furie BC. Role of platelet P-selectin and microparticle PSGL-1 in thrombus formation Trends Mol Med. 2004; 10: 171-8. Ref.: https://tinyurl.com/y5bnadm5

39. Barry OP, Practico D, Lawson JA, FitzGerald GA. Transcellular activation of platelets and endothelial cells by bioactive lipids in platelet microparticles. J Clin Invest. 1997; 99: 2118-2127. Ref.: https://tinyurl.com/y22um7yp 
40. Garcia B, Smalley DM, Cho H, Shabanowitz J, Ley K, Hunt DF. The platelet particle proteome. J Proteome Res. 2005; 4: 1516-1521. Ref.: https://tinyurl.com/y4vrf9w3

41. Sprague DL, Elzey BD, Crist SA, Waldschmidt TJ, Jensen RJ, Ratliff TL. Platelet-mediated modulation of adaptive immunity: unique delivery of CD154 signal by platelet-derived membrane vesicles. Blood. 2008; 111: 5028-5036. Ref.: https://tinyurl.com/y4gymbr8

42. Conway DS, Pearce LA, Chin BS, Hart RG, Lip GY. Plasma von Willebrand factor and soluble p-selectin as indices of endothelial damage and platelet activation in 1321 patients with nonvalvular atrial fibrillation: relationship to stroke risk factors. Circulation. 2002; 106: 1962-1967. Ref.: https://tinyurl.com/y5aapoc3

43. Siwaponanan P, Keawvichit R, Udompunturak S, Hunnangkul S, Reesukumal K, et al. Altered profile of circulating microparticles in nonvalvular atrial fibrillation. Clin Cardiol. 2019; 42: 425-431. Ref.: https://tinyurl.com/y5mf3552 w

44. Jesel $L$, Abbas M, Toti F, Cohen A, Arentz T, et al. Microparticles in atrial fibrillation: a link between cell activation or apoptosis, tissue remodelling and thrombogenicity. Int J Cardiol. 2013; 168: 660669. Ref.: https://tinyurl.com/y699dx4g

45. Horstman LL, Jy W, Bidot CJ, Nordberg ML, Minagar A, et al. Potential roles of cellderived microparticles in ischemic brain disease. Neurol Res. 2009; 31: 799-806. Ref.: https://tinyurl.com/yysq8hav

46. Choudhury A, Chung I, Blann AD, Lip GYH. Elevated platelet microparticle levels in nonvalvular atrial fibrillation: relationship to p-selectin and antithrombotic therapy. Chest. 2007; 131: 809-815. Ref.: https://tinyurl.com/y562s9lz

47. Choudhury A, Chung I, Blann AD, Lip GY. Platelet surface CD62P and CD63, mean platelet volume, and soluble/platelet P-selectin as indexes of platelet function in atrial fibrillation: a comparison of "healthy control subjects" and "disease control subjects" in sinus rhythm. J Am Coll Cardiol. 2007; 49: 1957-1964. Ref.: https://tinyurl.com/y3olruzu

48. Tan KT, Tayebjee MH, Lim HS, Lip GY. Clinically apparent atherosclerotic disease in diabetes is associated with an increase in platelet micro particle levels. Diabet Med. 2005; 22: 1657-1662. Ref.: https://tinyurl.com/y34kflz8

49. Kamath S, Blann AD, Chin BS, Lanza F, Aleil B, et al. A study of platelet activation in atrial fibrillation and the effects of antithrombotic therapy. Eur Heart J. 2002; 23: 1788-1795. Ref.: https://tinyurl.com/y4df4c72

50. Choudhury A, Chung I, Blann A, Lip GY. Platelet adhesion in atrial fibrillation. Thromb Res. 2007; 120: 623-629. Ref.: https://tinyurl.com/yxdmn3ry 